\title{
The Principal Management in Improving Teacher Performance in the Era of the Industrial Revolution 4.0 in SMP Banda Aceh
}

\author{
Susi Lailiana*, Murniati, Khairuddin \\ Master Program in Educational Administration \\ Syiah Kuala University \\ Aceh, Indonesia \\ *susi.lailiana2019@gmail.com
}

\begin{abstract}
This study aims to reveal the principal's efforts in improving teacher learning in the era of industrial revolution 4.0. Principal management in improving teacher learning must be following the learning objectives of students. Thus, good management is needed from the principal to improve teacher performance. This research design was a case study research with a qualitative approach. Participants in this study were the Principal of Junior High School in Banda Aceh. Research data collection was conducted through interviews and documentation. Data analysis was conducted by recording field notes, collecting data, reducing data, and drawing conclusions. The results show that the management of the principal in improving teacher performance is planning a school program that involves all school components and conducting a SWOT analysis which is then turned into a School Activities and Budget Plans as well as suggestions from various parties, both the community/students' parents.
\end{abstract}

Keywords-principal management, teacher performance, industrial revolution 4.0

\section{INTRODUCTION}

Currently, the world has entered the era of the industrial revolution 4.0. Everything becomes limitless and unlimited due to the development of the internet and digital technology, including education. There is a relationship between education and the 4.0 industrial revolution, that education is required to follow technological developments that are rapidly developing and utilize information and communication technology as more sophisticated and sophisticated facilities to facilitate the learning process. The main purpose of learning technology is to solve learning problems or facilitate learning activities [1]. The use of technology is expected to increase students' interest in learning because the conventional learning process is deemed unpleasant and monotonous [2].

Industrial revolution 4.0 is also known as the digital revolution and the era of technological disruption. It is called the digital revolution because of the advancement and interference of computers and automation of data recording in all fields. It is also said that it is an era of technological disruption due to automation and the connection of all fields, which will create non-linear industrial movements and job competition [3]. The industrial revolution 4.0 can shift the role of humans as one of its characteristics, namely the application of artificial intelligence [4].

The industrial revolution 4.0 has had a major impact on various fields, including education [5]. Technology-based learning needs to be implemented with the role of the principal. Learning using Android has been applied to SMP in Banda Aceh. The school has implemented this learning for one year. Based on the program, the principal is obliged to improve teacher performance, especially in implementing a technologybased learning process. The principal needs to choose the right management to assist teachers in improving their performance, especially in facing the era of the industrial revolution 4.0. Mistakes in implementing principal school management will significantly impact the success of increasing teacher professional competence.

As a leader in the school, the principal has a very important and strategic role and role [6]. One of them is the task of preparing teachers to improve the quality of learning. In line with the industrial revolution that occurred in the world of education in Indonesia and the duties of school principals, the ability of school principals must also be further enhanced and strengthened. Therefore, it requires adequate management of school principals following the changes that occur. This management aims to ensure that the principal is able to carry out his duties and roles properly [7]. One of the things that can be done in management is to strengthen the competence of school principals in supervising teacher learning activities. And it is hoped that this teacher learning supervision activity is in accordance with the industrial revolution 4.0.

The school principal plays a very important role in managing the resources owned by the school and carrying out their duties and authorities, which must be carried out properly in the industrial era 4.0. Thus the principal needs to have the ability to manage in order to successfully improve teacher 
performance [8]. The school principal carries out management by compiling programs that are suitable for learning in the Industrial Age 4.0. Everything is made based on the needs, goals, and expectations of education. Embracing teachers and teaching management to staff is the first step in building a quality school system [9]. The management of the principal influences teacher performance. In management, good leaders make plans that are structured systematically and effectively.

The success of improving teacher performance is, of course, seen from the success in the learning process. So, teachers must have good performance so that the learning process also runs smoothly, supported by the qualifications and competencies; besides that, teachers must also be disciplined in carrying out their duties. In junior high school in Banda Aceh, there are still teachers who have not mastered IT. Thus, the principal has the authority to improve teacher performance to be able to carry out their duties properly and in accordance with the school goals that have been set.

Previous researchers have conducted research related to learning in the industrial era 4.0. Previous research is about the impact of technology use in the industrial era 4.0 [10]. In addition, research related to management in improving the quality of schools in the industrial era 4.0 [11]. However, it has not been studied regarding the management of the principal in improving teacher performance in the era of the industrial revolution 4.0. This problem certainly cannot be ignored, so it is necessary to manage the principal to improve teacher performance on the quality of the learning process in the era of the industrial revolution 4.0. So this study aims to determine the management of school principals in improving teacher performance in the era of the industrial revolution 4.0 at junior high schools (SMP) in Banda Aceh."

\section{METHODS}

The research was conducted using qualitative methods, with a research design that is a case study. The research was conducted to reveal the focus of the research. The main focus of this research is the management of school principals in improving teacher performance in the era of the industrial revolution 4.0. The researcher acts as a key instrument in the research data collection process so that the research data is following the conditions in the field. Researchers also conducted participatory observations so that the research data obtained was better. In order to stay focused on the research focus, the researcher used an interview guide that was used to explore data and deepen the disclosure of the research focus. The interview guide is in the form of open answers presented by the participants.

Research data collection is obtained through interviews and documentation. Interviews were conducted with primary data sources, namely the head of SMP in Banda Aceh. Documentation was carried out by researchers on the school program instrument document. Data analysis begins by recording field notes, collecting data, reducing data, and drawing conclusions.

\section{RESULTS AND DISCUSSION}

The research results show that the management of the principal in improving teacher learning in the Industrial Revolution Era 4.0 is planning a work program so that its implementation can run according to predetermined guidelines. The principal of Junior High School in Banda Aceh as the highest leader in educational management in school institutions, has the task of carrying out management, namely creating programs that aim to improve teacher performance in the era of the industrial revolution 4.0.

The school program contains details of the activities needed by the school, what is needed and will be carried out, including, in this case, the management of teacher performance at the school to achieve technology-based learning in the era of the industrial revolution 4.0. Based on the results of observations of the program documents discussed, the researcher found that the planning of the junior high school program in Banda Aceh was made referring to the analysis of the weaknesses and strengths of the school or what is known as the SWOT analysis, which is then discussed and outlined in the School Activities and Budget Plans for the following year. School Activities and Budget Plans is a document that contains a school development program plan for the next year, which is compiled based on the School Activity Plan to address any gaps between reality and expectations towards meeting national education standards. School Activities and Budget Plans are school work plans or mid-term plans compiled in 4 years and an annual work plan

Education in the revolutionary era 4.0 certainly cannot be separated from the principal figure as managerial to improve teacher performance. The principal must be able to manage various technological developments in education, especially related to teacher performance, hoping that education will be better and more effective according to the needs of the generation in the era of the industrial revolution 4.0.

Based on the SWOT analysis, school program planning and quality development programs for teachers or junior high school teacher performance in Banda Aceh are also based on suggestions from various parties and student guardians. Principal management is analyzed using SWOT, which will eventually be outlined in the School Activities and Budget Plans. Related to the school program, which includes coaching the quality of educators to improve the performance of school principals, explained that the quality coaching program carried out related to teacher performance management in the era of the industrial revolution 4.0 was carried out in several ways including IT deepening programs, learning innovations and Subject Teacher Deliberations (MGMP)

The statement conveyed by the principal was corroborated by the findings of the Junior High School program documents in Banda Aceh related to improving teacher performance in the industrial era 4.0, which can be seen in the table 1 . 
TABLE I. SCHOOL PROGRAM PLANS IN IMPROVING TEACHER PERFORMANCE IN THE INDUSTRIAL ERA 4.0

\begin{tabular}{|c|c|c|c|}
\hline No. & Description of activities & $\begin{array}{c}\text { Implementation } \\
\text { Plan }\end{array}$ & Place of Activity \\
\hline 1 & Supervision & Quarterly & $\begin{array}{l}\text { Principal / } \\
\text { Classroom }\end{array}$ \\
\hline 2 & $\begin{array}{l}\text { Subject Teacher } \\
\text { Deliberation at the } \\
\text { school level }\end{array}$ & Quarterly & School hall \\
\hline 3 & Mastery of IT & First semester & $\begin{array}{c}\text { Computer } \\
\text { Laboratory Room }\end{array}$ \\
\hline 4 & $\begin{array}{l}\text { IT Based assessment } \\
\text { development }\end{array}$ & August, 2021 & School Hall \\
\hline 5 & $\begin{array}{l}\text { IHT SPMI } \\
\text { Development } \\
\text { (Internal Quality } \\
\text { Assurance System) }\end{array}$ & August, 2021 & School Hall \\
\hline 6 & $\begin{array}{l}\text { HT Development of } \\
\text { Learning } \\
\text { Implementation Plan } \\
\text { (RPP) Skills }\end{array}$ & August, 2021 & School Hall \\
\hline 7 & $\begin{array}{l}\text { Technical Guidance } \\
\text { for Learning and } \\
\text { assessing HOTS } \\
\text { questions }\end{array}$ & September, 2021 & School Hall \\
\hline 8 & $\begin{array}{l}\text { Strengthening IT- } \\
\text { Based Learning }\end{array}$ & September, 2021 & School Hall \\
\hline 9 & $\begin{array}{l}\text { Personal } \\
\text { Development for } \\
\text { Educators / Education }\end{array}$ & Adjust & Principal's Room \\
\hline 10 & $\begin{array}{l}\text { Workshop / } \\
\text { Technical Guidance } \\
\text { held by Government } \\
\text { Agencies }\end{array}$ & $\begin{array}{c}\text { In accordance with } \\
\text { the Invitation from } \\
\text { Government } \\
\text { Agencies }\end{array}$ & Adjust \\
\hline
\end{tabular}

Source: School program document, 202

Planning for a program to improve the performance of junior high school teachers in Banda Aceh has its objectives and targets, among which are to improve teacher performance which leads to improving the quality of education, developing teacher competence. In addition, to improve the quality of education, it is also hoped that it can increase competitiveness to increase educational personnel or school human resources in the era of the industrial revolution 4.0.

Principal management to improve teacher performance in the industrial revolution 4.0 is an activity in the school program. The program begins with planning, which is an action that will be taken to obtain a specified result in a certain time frame and space. Thus, planning is a thought process, both in outline and in detail, from an activity/work undertaken to achieve the best and most effective certainty. Planning is an anticipation of something that will happen because it must be done with the best possible process [12].
Based on the results of this study, it can be seen that the management of school principals in improving the performance of junior high school teachers in Banda Aceh is as follows:

- Planning school programs that involve all school components including the principal, vice principal in the field of curriculum, students, infrastructure advice, community relations, treasurers, educators and school committees.

- Conducted a SWOT analysis and described it in the form of School Activities and Budget Plans and suggestions from various parties, either the community or the students' parents.

Based on these results, the management of school principals who can improve the performance of junior high school teachers in Banda Aceh begins with a program planning meeting to accommodate all school activities, including curriculum, student affairs, infrastructure, and public relations, which are mapped into short, medium and long term programs based on school SWOT analysis, and then outlined in the School Activities and Budget Plans.

The school program is a document that must be prepared and owned by a school principal as a reference for carrying out his duties as the principal of the school itself. This is following what was conveyed by the principal of Junior High School in Banda Aceh, who stated that, as the principal of the school, he already had a special guideline that had been agreed upon which would be used as a reference and guide regarding the planning that would be carried out in the future.

In addition, based on interviews with the principal, the principal provides feedback on teacher performance, identifies teacher needs, conducts quality assurance checks, ensures teacher motivation, morale, provides professional support and guidance. The principal ensures that a professional environment supports the teaching and learning process. Besides, the principal has a school program to improve teacher performance in the industrial revolution 4.0, which is the school's strategic plan. Such as the research results that the principal's vision will determine which direction the educational institution is taken, because if the principal does not have a far-reaching idea, he will only carry out his duties as a daily routine, without knowing what progress must be achieved within a certain period of time [13].

Regarding the planning of school quality support programs, it is carried out by the principal together with teachers, employees, and parents of students. Together with teachers and staff, gathers the principal gathers in advance in a forum to analyze what programs are needed by teachers and students in schools - things done by junior high schools in Banda Aceh. Management in the step of determining the program, namely disseminating the concept of quality assurance programs to all school members, conducting target analysis, formulating targets based on the vision, mission, and goals of the school, conducting a SWOT analysis, compiling quality improvement plans, and formulating new quality objectives [14]. 
In this context, SMP in Banda Aceh has also carried out according to the objectives and meaning of the program management function carried out by Junior High School in Banda Aceh, which is carried out or begins with a meeting that accommodates all school activities, including curriculum, student affairs, infrastructure, and community relations, which are mapped into long-term programs. Short, medium, and long term based on a school SWOT analysis, further outlined in the School Activities and Budget Plans. Implementing the agreed school program in the form of School Activities and Budget Plans is the implementation reference concerning the financing and timing of all programs to be implemented

Thus the management carried out by the head of the Junior High School in Banda Aceh in improving teacher performance in the era of the industrial revolution 4.0 has covered all things well where thus the objectives of the planning management function can be achieved properly so that it has an impact on school goals and ultimately affects the quality of the school.

From the description of the study results, the implementation of the management of junior high school principals in Banda Aceh in improving performance such as IT Deepening activities, Subject Teacher Deliberations at the school and national levels, personal coaching, supervision, and technical guidance. The implementation of the activity program is carried out in several stages, namely coordination by the committee / implementing team, implementing activities according to the scheduled plan, applying teacher absenteeism to each activity, implementing personal coaching, and finally encouraging teachers to continue to a higher level.

The management is carried out according to the appropriate stages. Thus, in terms of management, the implementation of improving the performance of junior high school teachers in Banda Aceh has been good. In accordance with the results of research, which concluded that the development of teacher performance is a job that the principal must do in education personnel management, which aims to empower teachers effectively and efficiently to achieve optimal results [15].

An important aspect of management in education is empowering teachers and giving them broad powers to improve learning in the industrial era 4.0 [16]. Similar to what was done by the head of junior high school in Banda Aceh, the principal actively involved teachers in workshop activities, Subject Teacher Deliberations, IT Deepening, Personal Coaching for Educators; the principal accommodated these educational activities to improve the performance of teachers and staff in schools. Thus, the implementation function in the performance management of junior high school teachers in Banda Aceh in the form of a program to improve the quality of teaching staff is implemented properly and in accordance with existing regulations.

Based on the descriptions presented, the researcher can conclude that the management of school principals to improve the performance of junior high school teachers in Banda Aceh in the era of the industrial revolution 4.0 began with a meeting involving all school components, using SWOT analysis and suggestions from various parties, proposing student meetings parents and then poured into the School Activities and Budget Plans for the achievement of the following year. Furthermore, the program's implementation is implemented according to the stage as planned/prepared in advance so that the implementation of the management goes well.

\section{CONCLUSIONS}

Based on the results conducted at junior high schools Banda Aceh regarding principal management in improving teacher performance in the era of the industrial revolution 4.0, it can be concluded that the management of school principals in improving the teaching performance of junior high school teachers in Banda Aceh is accommodating all good school activities, curriculum, students, infrastructure, and public relations are mapped into short, medium and long term programs based on the school's SWOT analysis. Furthermore, all these activities are outlined in the School Activity and Budget Plans (RKAS) and carried out according to a wellprepared plan

\section{ACKNOWLEDGMENTS}

The researchers would like to thanks all who played a role in the research, so that this research can be completed properly. Special thanks to the Educational Administration Masters Study Program, Syiah Kuala University, who supported this research until its completion. Furthermore, the Junior High School in Banda Aceh has permitted researchers to finish the research.

\section{REFERENCES}

[1] I. Haris, "School Supervision Practices in the Indonesian Education System; Perspectives and Challenges," Journal of Social Studies Education Research, vol. 9, pp. 15-23, 2018.

[2] A.A. Hussin, "Education 4.0 Made Simple: Ideas for Teaching," International Journal of Education \& Literacy Studies, vol. 6, pp. 13-21, 2018.

[3] B. Abersek, "Evolution of Competences for New Era or Education 4.0," disajikan dalam seminar Impact of Technologies in the Sphere of Education and Educational Research. Czech Educational Research Asosiation (CERA/CAPV), Czech, 13-14 September 2017.

[4] J.M. Allen, "Project Evidence: Responding to the Changing Professiona Learning Needs of Mentors in Initial Teacher Education," Australian Journal of Teacher Education, vol. 42, pp. 56-62, 2017.

[5] V. Puncreobutr, "Education 4.0: New challenge of learning," St. Theresa Journal of Humanities and Social Sciences, vol. 2, 2016.

[6] T.M. Kin, and O.A. Kareem, "School leaders' Competencies that make difference in the Era of Education 4.0: A Conceptual Framework," International Journal of Academic Research in Business and Social Sciences, vol. 9, pp. 214-225, 2019.

[7] P.D. Brett, "Learning the Words: Supervising Teachers and the Language of Impact in an Initial Teacher Education Programme," Australian Journal of Teacher Education, vol. 43, pp. 25-31, 2018.

[8] B. Oberer and A. Erkollar, "Leadership 4.0: Digital Leaders in the Age of Industry 4.0,". International Journal of Organizational Leadership, vol. 7, pp. 404-412, 2018. 
[9] W. Wallner and W. Wagner, "Academic Education 4.0," Int. Conf. Educ. New Dev., vol. June, pp. 155-159, 2016.

[10] T.S. Triwiyanto and L.D. Prasojo, "The Thoughts of Ki Hadjar Dewantara and Their Implications for School Management in the Industrial Era 4.0," International Journal of Innovation, Creativity and Change, vol. 5, pp. 197-208, 2019.

[11] S. Sunarijah, "Manajemen Meningkatkan Mutu Sekolah Dasar Menghadapi Era Revolusi Industri 4.0" Jurnal Ilmiah Pendidikan Agama Islam, vol. 8, pp. 11-19, 2018.

[12] N.W. Gleason, "Higher education in the era of the fourth industrial revolution," Palgrave Macmillan, 2018.

[13] R. Thannimalai and A. Arumugam, "The Influence of Principals' Technology Leadership And Professional Development on Teachers'
Technology Integration In Secondary Schools," Malaysian Journal of Learning and Instruction, vol. 15, pp. 45-52, 2018.

[14] D. Li, "Supervising Asian International Counseling Students: Using the Integrative Developmental Model, "Journal of International Students, vol. 8, pp. 36-41, 2018.

[15] S. Mathodah, "Kompetensi Manajerial dan Keteladanan Pimpinan Terhadap Kinerja Guru," Scientific Journal Of Reflection: Economic, Accounting, Management And Business, vol. 2, pp. 162-170, 2019.

[16] M. Rofiki, "Urgensi Supervisi Akademik dalam Pengembangan Profesionalisme Guru di Era Industri 4.0," Indonesian Journal of Basic Education, vol. 2, pp. 15-23, 2019. 